Illinois State University

ISU ReD: Research and eData

Theses and Dissertations

3-18-2016

\title{
Analyzing Twitter Usage Differences Between Student Season Ticket Buyers And Non-Buyers
}

Matthew Aloysius Kinney

Illinois State University, mkinne2@ilstu.edu

Follow this and additional works at: https://ir.library.illinoisstate.edu/etd

Part of the Sports Management Commons

\section{Recommended Citation}

Kinney, Matthew Aloysius, "Analyzing Twitter Usage Differences Between Student Season Ticket Buyers And Non-Buyers" (2016). Theses and Dissertations. 512.

https://ir.library.illinoisstate.edu/etd/512

This Thesis is brought to you for free and open access by ISU ReD: Research and eData. It has been accepted for inclusion in Theses and Dissertations by an authorized administrator of ISU ReD: Research and eData. For more information, please contact ISUReD@ilstu.edu. 


\title{
ANALYZING TWITTER USAGE DIFFERENCES \\ BETWEEN STUDENT SEASON TICKET \\ BUYERS AND NON-BUYERS
}

\author{
Matthew A. Kinney
}

\section{Pages}

This thesis investigates the importance of social media to college students as it relates to purchasing ticket membership packages. More specifically, the thesis examines the role that Twitter and marketing play in student decisions to purchase ticket memberships and what if any constraints exist from attending. The results demonstrate that those who have purchased a ticket membership package are more likely to follow said organization on Twitter. However, results also found that no significant difference exists in Twitter usage based on whether or not a student has purchased a ticket membership package.

KEYWORDS: College Athletics, Marketing, Social Media, Sports, Ticket Sales 


\title{
ANALYZING TWITTER USAGE DIFFERENCES \\ BETWEEN STUDENT SEASON TICKET \\ BUYERS AND NON-BUYERS
}

\author{
MATTHEW A. KINNEY
}

A Thesis Submitted in Partial Fulfillment of the Requirements for the Degree of

\section{MASTER OF SCIENCE}

School of Kinesiology and Recreation

ILLINOIS STATE UNIVERSITY 
Copyright 2016 Matthew A. Kinney 


\section{ANALYZING TWITTER USAGE DIFFERENCES BETWEEN STUDENT SEASON TICKET BUYERS AND NON-BUYERS}

MATTHEW A. KINNEY

COMMITTEE MEMBERS:

Clinton J. Warren, Chair

Rebecca Achen

Brent Beggs 


\section{ACKNOWLEDGMENTS}

The writer wishes to thank Dr. Warren, Chairperson of his Advisory Committee, for his dedication, support and unwavering commitment to this thesis project. Dr. Warren, even in all the times of doubt and me being unsure if I was heading in the right direction on this project you were the voice of influence.

The writer would also like to thank Dr. Achen and Dr. Beggs for their help throughout this project. Without Dr. Beggs, this process would not have been able to happen, as well as Dr. Achen for providing her expertise in this subject matter that I myself was wanting to further study. Throughout the past year, both Dr. Beggs and Dr. Achen have provided help whenever needed which greatly strengthened the project overall.

Finally, to my wife, you have always been willing to put up with me when the going gets tough, and this project is no exception to that. Many of days and nights went by where I had to focus my attention upon this project instead of spending it with the love of my life, but you were always willing to be positive and understanding of the process. To everyone else who has helped me through this process, I cannot express enough how much help you have all been. The support and encouragement that I have received throughout this project has been great. Thank you.

M. A. K. 


\section{CONTENTS}

ACKNOWLEDGMENTS $\quad$ i

$\begin{array}{ll}\text { CONTENTS } & \text { ii }\end{array}$

TABLES $\quad$ iv

CHAPTER

I. INTRODUCTION 1

$\begin{array}{ll}\text { Definition of Terms } & 8\end{array}$

II. REVIEW OF RELATED LITERATURE 9

Communications $\quad 9$

$\begin{array}{ll}\text { Marketing } & 10\end{array}$

$\begin{array}{ll}\text { Social Media Marketing } & 11\end{array}$

$\begin{array}{ll}\text { Social Media Marketing in Sport } & 18\end{array}$

Ticket Sales in College Athletics $\quad 21$

Spectator Motivations and Constraints for Attendance 23

$\begin{array}{ll}\text { Students as Fans } & 28\end{array}$

III. METHODOLOGY 33

Research Questions $\quad 34$

Research Design $\quad 34$

Data Collection Procedures $\quad 34$

Survey Instrument $\quad 35$

Study Variables $\quad 35$

Data Analysis 36

IV. RESULTS 38

$\begin{array}{ll}\text { V. DISCUSSION } & 42\end{array}$

Summary of the Research Findings $\quad 42$

Study Limitations $\quad 44$ 
REFERENCES

APPENDIX A: Survey Instrument 


\section{TABLES}

Table $\quad$ Page

1. Cross Tabulation Analysis 39

2. T-test Analysis on Twitter Intensity and Consumer Involvement 40

3. T-Test Analysis on Constraints 40 


\section{CHAPTER I}

\section{INTRODUCTION}

When the social media site Facebook was founded by Harvard student Mark Zuckerberg in 2003, nobody could have pictured the social media revolution that was about to take place. Facebook found its initial niche by allowing only college student users for the first two years (Kornblum, 2006) instead of being open to the public. In 2006, Twitter changed the way that consumers viewed social media by limiting users to writing messages in 140 characters or less. This simplicity has led to tremendous growth in popularity over a short period of time. Additionally, as cell phones have evolved to include greater Internet capabilities, photo applications such as Snapchat and Instagram have been the newest social media sites to change the way users connect, and the way in which people view social media as a networking tool to stay in contact with friends. Like many other products that have evolved over time, businesses eventually caught onto the social media craze and started looking for a way to harness its powerful effects through the use of social media marketing.

With a growing user base and rising costs for the need of additional servers to support the user base, Facebook is credited with being the first social media website to have advertising appear to its user base. Initially, the advertising opportunity that started only months after Facebook was created was only provided to companies that were likely to offer services to college students. Soon after, Facebook had advertisers lining up to get a chance to reach the younger demographic that used the social media site. After 
incorporating advertising on their platform, Facebook saw revenue increase from an initial $\$ 382,000$ in 2004 to a hefty $\$ 5$ billion in 2012 (Fiegerman, 2013). Looking at social media today, businesses and companies of all sizes use social media in a multitude of ways to reach as many consumers as possible making social media marketing one of the most important tools that a company can currently use to attract new customers in a cost-efficient manner. Using social media from a business perspective is cost-effective, meaning that any interactions that a business can create with a potential consumer is free marketing that is much more likely to seen by consumers than other traditional marketing means (print newspaper, magazine advertisement, radio advertisement).

There are 1.2 billion active Facebook users and over 271 million active Twitter users (Brodzky, 2014). This makes the social media platforms number one and three respectively in terms of active users, while one of the newer social media platforms, Instagram, ranks second (Brodzky, 2014). Furthermore, 23.3 percent of Facebook users fell in the ages 18-24 demographic while 35 percent of Twitter users were aged between 18-29 making these two demographics account for 137 million active users between the two social media platforms (Brodzky, 2014). Not only does the millennial demographic (any person born from the early 1980's to the late 1990's) rank as the largest demographic in terms of social media users, but as of July 1, 2014 the 18-29 age demographic accounted for 53.5 million (16.8\%) people in the United States population while 75 million people (23.5\%) in the U.S. fell into the 18-34 age demographic (Brodzky, 2014). Much of this social media usage by the 18-29 age demographic could be attributed to the fact that during the second quarter of 2014, Nielson Online (2014) found that 85 percent of all people aged 18-24 owned and used a smartphone, which 
gives the user the opportunity to access their social media pages on their mobile device in addition to many other options.

Understanding the importance of this demographic is imperative for many businesses as estimates show that one in three employees in the United States is currently a millennial (Schwabel, 2013). In addition to making up a large portion of the U.S. workforce, purchasing trends made by millennials are likely to cause a change in the way that both marketers and businesses operate. Choosing to ignore or not put forth a conscious effort towards the marketing to millennials is likely to cause devastating problems for businesses as an estimated $75 \%$ of the global workforce will be a millennial by the year 2025 (Schwabel, 2013). Furthermore, the millennial generation is unlike any other generation due to their digital tendencies and technological savvy which changes the way in marketers engage with them as consumers (Nielsen, 2014).

Another area in which understanding and marketing to the millennial demographic is an ongoing challenge is in college athletics. College athletic departments face many unique challenges when it comes to satisfying the needs and wants of millennials. One such challenge is with regard to selling tickets to athletic events. Not only do athletic departments attempt to sell tickets to campuses of millennials they sell to a very diverse group of people that only share the athletic program as a common interest. Furthermore, the number of sports that a college athletic department is trying to sell tickets for creates more supply of available events to attend than the demand that exists. This problem is compounded by the fact that many athletic departments are forced to rely on student workers or interns that have little or no experience and are not working full time, meaning that athletic departments are having to train new employees on a yearly 
basis. Some colleges have since gone as far as to outsource their ticket sales to a thirdparty. This strategy significantly cuts down on the amount of potential revenue available and creates problems such as poor communication between the third-party and the athletic department (Bouchet, Ballouli, Bennet, 2011). Regardless of whether the ticket sales in an athletic department is outsourced or not, compensation will always remain a significant issue "because many state-supported universities have bylaws forbidding administration to grant commissions or bonuses to employee staff" (Bouchet, Ballouli, Bennett, 2011).

For some college athletic departments, the added expenses that have been incurred since 2004 have been covered by the large amounts of revenue that are being brought in by their portion of a conference television contract. Of the 14 schools in the Big 10 Conference, the conference office projects that when the new television contract starts in the 2017-18 season that 12 of these schools will bring in $\$ 44.5$ million in television revenue per year (Carmin, 2014). This added revenue seems as though a college athletic department would be able to offset the expenses that are incurred by sponsoring non-revenue generating sports and invest the extra revenue back into the athletic department, but this does not take into account the added costs that some schools are undertaking to broadcast these events as well as the lost income from fans who decide to watch the event from home instead of attending. Research has shown that attendance has slowly seen a decline at sporting events as more games are televised, and some conferences have gone as far as to schedule football games on weeknights so that the game can be televised to gain this television revenue (mac-sports.com, 2014). 
More recently, a new challenge has caused major waves across a majority of college athletics as many colleges are now facing the new reality of covering full cost of attendance, which up until 2013 was only an athletic scholarship to cover tuition, fees, and, books, and room and board. In addition to the four items listed above, the new full cost of attendance scholarship also includes other typical expenses such as academicrelated supplies and transportation that a college student would have. (Hosick, 2015). In addition to these added costs that these athletic departments are being expected to cover, athletic departments are also facing a rising issue that involves a large decline in funding and ticket sales. With donations and ticket sales making up the largest single sources of revenue streams for many college athletic departments, the increase in expenses outweighs the increased revenue meaning that many schools are facing the challenge of cutting "resource draining" sports (Weiner, 2009). Required donations can likely make up for some of the lost revenue in ticket sales as some colleges with large fan bases now require donations for the right to purchase tickets to an athletic event, but other available revenue sources (conference payouts from television contracts, marketing income) are not as flexible as ticket sales (Weiner, 2009). For those schools that rely on student attendance to fill the gap, all students regardless of whether they attend athletic events or not are required to pay what amounts to 18 percent of the athletic budgets (Fulks, 2006).

Prior to the start of the 2014-15 academic year, athletic scholarships awarded to student-athletes only covered academic expenses, since colleges did not recognize other expenses as being academic in nature. With the new full cost of attendance measures, schools that choose to cover the full cost of attendance now must add a monthly stipend to each athletic scholarship to help offset living expenses that the student-student athlete 
might have with each school having different stipend amounts depending on the location of the school. While the 65 schools in the major conferences that must offer the full cost of attendance stipend to their student-athletes might not have as much trouble covering this additional expense, this added burden for those outside the major conferences that decide to pick up this extra expense must find a way to cover it, which can average anywhere between $\$ 2,000$ and $\$ 5,000$ per athlete per year (Prisbell, 2014). If a school decides not to offer full cost of attendance stipends, then the school faces the possibility of losing out on student-athletes that they once had no trouble attracting to play at the college due to "considerable leeway and subjectivity in how schools determine their costof-attendance figures" thus leading to recruiting advantages (Berkowitz, 2015).

For smaller colleges this problem is even more detrimental, because the following behind these college athletic programs is likely not as large as a major university, putting an emphasis on students to fill the empty seats at sporting events. This has led some schools to sell unsold student tickets to the general public to attempt to recoup some of the lost revenue when students do not buy tickets. This strategy has long term ramifications such as alienating potential future donors once students graduate and become alumni. Millions of dollars are being invested into athletic facilities to enhance the fan experience to attract more fans and appear to the millennial demographic, as "The last 10 years have brought an unprecedented building boom for athletic programs on campuses across the United States, with at least $\$ 15.2$ billion spent on sports facilities, according to research compiled by SportsBusiness Journal” (King, 2005). Even with the new upgrades in technology that are constantly being added to these athletic facilities, 
overall student attendance is down 7.1 percent since 2009 meaning there is no guarantee that facility upgrades will attract more fans (McClellan, 2014).

Student attendance at college football games has become such an issue that even schools with recent success have had issues filling their student sections. One example of this would be at the University of Alabama, who despite winning three national championships in a four year period still sees the percentage of student tickets used hover between 68.4 and 71.8 percent in that four year span (Steinbach, 2013). Other schools that have problems filling the student seats have questioned raising the price of student tickets because students feel as though the price they pay for tickets is not significant enough (Steinbach, 2013). This doesn't appear to be the issue at all schools though as the University of Ohio allows students to attend games for free, seeing "student attendance at football games has increased 85 percent since 2008-2009” (Steinbach, 2013). This issue leaves both marketers and ticket sales offices with questions as to how and or what exactly motivates millennials to attend games, as millennials will make soon make up the majority of those who attend games.

In sum, college athletic departments are faced with the same challenge as forprofit businesses as it pertains to marketing and selling products to millennials. With the popularity of social media marketing and its potential to connect with millennials this study seeks to understand the importance of social media to college students as it relates to purchasing game tickets. More specifically, the study examines the role that Twitter and marketing play in purchase intentions of students that actually purchase ticket memberships. This study is unique in the fact that student attendance at college sporting events has declined in the recent years, forcing marketers to use alternative marketing 
methods to entice students to purchase tickets. Furthermore, as collegiate athletic departments look for alternative funding methods to make up for a decrease in funding, it is imperative for collegiate athletic departments to maximize the amount of revenue possible through ticket sales to students and establish a connection between the student and athletic department that extends beyond the student's time at the college.

\section{Definition of Terms}

Constraint - Factors that are perceived or experienced by individuals to limit the formation of leisure preferences and to inhibit or prohibit participation and enjoyment in leisure. (Jackson, 1997)

Involvement - a motivational construct which partly relies on the antecedent factor of the person's values and needs (Zaichkowsky, 1986).

Social capital - the sum of the resources, actual or virtual, that accrue to an individual or a group by virtue of possessing a durable network of more or less institutionalized relationships of mutual acquaintance and recognition (Bourdieu and Wacquant, 1992). Engagement - A consumer relationship that recognizes that people are inherently social and look to create and maintain relations not only with other people, but also with brands (Sheehan and Morrison, 2009). 
CHAPTER II

\section{REVIEW OF RELATED LITERATURE}

\section{Communications}

With the upbringing of Social Media Sites and the way in which they are used, Ellison, Steinfeld, and Lampe (2007) examined the relationship between Facebook use and the formation and maintenance of social capital. This study was conducted due to the possibility that new forms of social capital and relationships could be built in online Social Networking Sites. Using Facebook as the Social Media site, Ellison, Steinfeld and Lampe (2007) wanted to know whether or not offline social capital can be generated by online tools. Previous research has shown that social capital has a positive effect on a variety of social aspects, but no research had been conducted regarding social media use and how it relates to social capital.

A random sample of 800 undergraduate students from Michigan State University were used in the study, with the survey being sent through campus email with a total of 286 students responding to the survey. Results from Ellison, Steinfeld, and Lampe (2007) show that there is a positive relationship between certain kinds of Facebook use and maintaining and creating social capital. Furthermore, Facebook appears to play an important role in the process by which students form and maintain social capital, with usage associated with three kinds of social capital (bridging, bonding, and maintained) included in the survey instrument (Ellison, Steinfeld, and Lampe, 2007). Due to 
limitations in the study, more research is needed to help understand data over a series of time including tracking first year students and following them through graduation.

\section{Marketing}

Before the time of the internet and social media, Zaichkowsky (1986) seeked to further understand the motivational state of involvement and how it affects the use of advertisements and purchase situations. Using the previously created Consumer Involvement Profile which measured the antecedents of involvement, Zaichkowsky's (1985) Personal Involvement Inventory (PII) measured involvement levels for advertising. By achieving three goals in the study (show that the PII is applicable to advertising, Show that the PII can be reduced by half without significantly reducing reliability, and Demonstrate that the PII can capture emotional and cognitive types of involvement), this study provides a useful segmenting tools for future researchers who wanted to group consumers with low or high involvement with respect to advertisements.

The original concept of the Personal Involvement Inventory included products and purchase situations in addition to advertisements, which is still used. Results showed that the Personal Involvement Inventory could be reduced from 20 items to 10 items without reducing reliability. Furthermore, Zaichkowsky (1986) was able to find that there is some indication that the revised PII may be broken into two subscales representing a cognitive and affective grouping. The validity of the subscales cannot be confirmed by the studies as it is not clear with the present research that affective and cognitive types of involvement. 


\section{Social Media Marketing}

Social media marketing in a non-sport context is employed by business due to the recent changes that have been caused by the Internet that led to business being able to directly engage customers in a way that is more cost-efficient to the business than traditional ways of marketing. Social media have allowed for a number of different industries worldwide to use the changes presented and engage customers in ways that have never been possible, though with unforeseen consequences if not used in the right way. For organizations to be successful from a business perspective, they must first understand customer engagement to turn customers into fans by progressing through the stages of the customer engagement cycle. Sashi (2012) attempted to further understand the different strategies used for customer engagement as well as develop new strategies regarding how organizations can use customer engagement in a social media setting.

Sashi (2012) found that for an organization to achieve customer engagement the organization must facilitate the consumer through seven stages (connection, interaction, retention, commitment, advocacy, and engagement) in the customer engagement cycle. While traditional methods of marketing required all seven steps to take place in-person, both organizations and consumers can now complete the cycle through the use of social media, allowing for the consumers to influence others in their social media networks.

Organizations must also be aware of potential issues that exist from this value created as consumers can just as easily influence others against the organization if a bad relationship were to exist between the consumer and organization, making social media both valuable and dangerous to the organization at the same time. More research is required to understand how different social media mediums can be combined with 
traditional forms of marketing (TV advertising, personal selling) to more effectively enhance advocacy and customer engagement (Sashi, 2012).

Nair (2011) looked into how organizations handle the issue of cost in addition to the measurement aspect of social media. Due to the diverse array of social media sites and the way that they are used, businesses are not able to measure the value of using social media without first understanding what each site is used for. Organizations who do not use social media run the risk of the losing out on customers, marking the importance of Nair (2011) to conduct this study. Looking at past experiences that businesses have had, this research is able to answer the questions of how to monetize social media in terms of engaging customers as well as what success looks like.

The biggest takeaway businesses could use from Nair (2011) is that social media is an entirely new way to communicate with potential customers and that unlike other forms of communication, listening to the customer is vital. Being transparent and letting consumers direct the conversation will allow for businesses to learn more about their customers, leading to a better marketing plan that meets consumer wants and needs. Using the health industry as an example, consumers now have access to more information than ever before due to social media as $83 \%$ of patients who visit the doctor now search online for health information (Nair, 2011). More than anything, social media is a new tool for businesses to not only communicate and market to potential consumers but also gives businesses a valuable tool to be able to listen and understand what it is the consumers want. Additional research still needs to be conducted if businesses want to answer questions such as when to engage with consumers and how to manage social media because of the strength of the variables in these decisions (Nair, 2011). 
Schultz and Peltier (2013) looked at both sides of the spectrum in their research, which looked at how social media both benefits and potentially harms consumer-brand engagement. Instead of putting together any sort of strategic plan on how to use social media to their advantage, many companies have journeyed into using social media due to fears of being left behind (Harvard Business School, 2010). Other issues such as the decline in more traditional forms of consumer communications as well as the current number of users on the main social media sites has caused businesses to take on a new approach in how to market products to consumers. The biggest of these issues seems to be though that businesses are being forced to realize that social media was created for use by people and not brands meaning that they must find a viable way to market products using social media.

What Schultz and Peltier (2013) found was that a majority of marketing initiatives are being directed towards consumers that are already engaged with their brand. Furthermore, many of these marketing efforts have not resulted in as successful of results as businesses had initially thought. The low success rates of could be attributed to the marketing efforts being deemed sales promotions instead of communication with consumers, although not all businesses suffer these problems. For businesses to truly know if social media can be used as a successful marketing tool for consumers, more research must be conducted regarding the consumer engagement and how social media is utilized by both businesses and consumers.

Ashley and Tuten (2015) studied how social media is being used by some of the current top brands in terms of social media usage and how their strategies relate consumer engagement on social media. With past research (Ling, 2004) showing that 
businesses should use social media to frequently produce content that is new and offers consumers incentives for participation, Ashley and Tuten's (2015) study is able to view what type of strategies brands that have been recognized for their social media efforts use to make their presence known. Currently, brands face the struggle of many consumers using social media as a way to consume content instead of actually publish their own content meaning that businesses are not able to gain as much valuable information regarding consumers (Nair, 2011). Furthermore, marketing content that is created for social media differs from marketing content that is used more traditional forms of media meaning that brands must find how the strategy differs to become successful.

Frequency use was the biggest finding in Ashley and Tuten's (2015) study as results found that brands that used social media sites at a more frequent basis had the highest number of people connecting with them and higher engagement levels. Some of the engagement could be attributed to the brands offering incentives to participate, as further results showed that more consumers would connect with the brands that offered incentive for participation. Focusing on specific social media channels also tended to create better results in addition to using a variety of strategies to put out a message keeps from alienating consumers. It must be taken into consideration that Ashley and Tuten's (2015) study was limited both the brands that were looked at (28) as well as the amount of content that was viewed for each brand (one week of content on each social media site), meaning more research is necessary to understand the full effects of how successful the strategies that these brands use on social media actually are.

Carlson and Lee (2015) looked specifically at the college level consumer demographic and the effectiveness of customer relationship management (CRM) on 
social media sites. This study was conducted to further understand how a business can utilize social media to better communicate and market their product as well as what role social media specifically has in the success of a business. Focusing on the college level consumer demographic was imperative to this study as the Millennial demographic is the first generation to spend more of their time on the internet than watching television (Carlson and Lee, 2015). Furthermore, studying the college level consumer demographic allows for businesses to gain valuable information regarding this demographic and track their purchase behaviors over time.

Carlson and Lee (2015) found that organizations should put a focus on improving relevance on social media platforms to build and sustain long-term success. Participants in the study were also asked to rank social media platforms in terms of importance with Facebook, YouTube, and Twitter ranking as the top three, thus allowing for businesses to focus on social media platforms that appeal to the college level demographic. Although results of the study were significant, limitations included a small sample size (150 students) in addition to the study only being given at one university. Additionally, the relationship that exists between a consumer following a brand on social media and purchasing the product was not looked at which leads to more research needing to be conducted.

Goodrich and Mooij (2013) researched how cultural dimensions are compared as it pertains to using social media to influence the consumer decision-making process. At the time this study was conducted, there was only a limited amount of research conducted regarding how marketers should use social media with even less known knowledge of the potential differences in consumers that reside outside of the United States. Individual in 
50 different countries were surveyed in the study in order to assess differences across nations while taking into consideration their access to social media and other internet influences (Goodrich and Mooij, 2013). Furthermore, social networking sites that are local to each country typically generate more traffic than omnipresent social media site in addition to different focuses as to why social media is used in different cultures.

Results for Goodrich and Mooij (2013) found that cultural differences play a role in both online and offline decision making processes. While individualistic countries such as the United States, United Kingdom, and Australia are less likely to make purchase decisions based on social media, collectivistic cultures such as China and Thailand see social media as playing an important role in forming an opinion about a product. Additionally, results also showed marketers that individualistic cultures are more likely to directly complain to the company if the product does not satisfy them while collectivistic cultures will make their voice heard in a group setting such as a confidential survey or social media site. While these results uncover potential cultural differences that exist in terms of successful marketing communications, further research is necessary to better understand each of the countries specific cultural differences.

Looking at how Fortune 500 companies use social media to interact with customers, Culnan, McHugh and Zubillaga (2010) studied what it takes for these companies to gain what is considered "full value" by using social media. By focusing on social media platforms Twitter, Facebook, blogs, and client-hosted forums, the research conducted is able to study social media platforms that are not used for content sharing but rather those that tend to have more engagement between two users. For value to be created, a company must understand that each social media platform can be used in a 
variety of ways and just using social media for e-commerce activities will not lead to success. Although the research study looks at examples from Fortune 500 companies, companies of all sizes will be able to utilize the results to make their business more valuable.

What Culnan, McHugh, and Zubillaga (2010) found was that each company needs to develop an implementation strategy to gain the most possible value. This implementation strategy is based on the elements of mindful adoption, community building, and absorptive capacity. Using these elements will allow for a company to make an informed decision about how to use each social media platform they choose to be on and establish a sizeable community that leads to more value. After the first two elements of the implementation strategy are conducted, businesses will then be able to focus on developing guidelines employees can use to monitor and process messages about the company being posted by users and track other potential problems that can happen.

Rosendale (2015) researched how corporate businesses now use social media and the impact it has on the branding aspect for a business. Looking at four main themes (increased transparency, stakeholder interaction and involvement, speed/cost/credibility benefits and market expansion), Rosendale's study looked at how branding is becoming more personalized due to the advent of social media and what businesses are doing to meet the needs of consumers. Being able to successfully use social media as a branding tool requires that businesses understand their target market and the preferences that these consumers have towards marketing communications. Branding through social media is likely to reach younger consumers while potentially alienating consumers who do not use 
social media, meaning that older methods of branding will also need to be used to reach the largest possible consumer market available.

Using social media as a branding tool also has its drawbacks, as Rosendale (2015) noted that no clear way of measurement is currently available to determine the effectiveness of using social media to influence consumers. Furthermore, the speed at which information travels on social media could prove costly when negative information about the business is released. Using social media also takes away from the amount of control that a business has over the content and design posted due to specific limitations that each social media site has. Overall, corporate businesses first must understand both the positives and negatives that can come from social media before finding a way to use social media as a way to meet the needs of the consumer in order to be successful.

\section{Social Media Marketing in Sport}

Understanding that social media marketing in sports is ubiquitous, Witkemper, Choong Hoon and Waldburger (2012) looked into Sport Twitter Consumption (STC) to further understand what motives and constraints influenced consumers to use Twitter in regards to following athletes. While other studies have been conducted in regards to motivations and constraints of social media users individually, this study examined both of these issues simultaneously to gain a better understanding of how each one affects the other. This study is important in the fact that in a one-year period from February 2008 until February 2009, Twitter increased their amount of users from 475,000 to over seven million marking a 1,400 percent growth. Currently, Twitter has over 200 million registered users. 
Witkemper, Choong, Hoon and Waldburger's (2012) results were derived from measuring four different limitations (skill, accessibility, economic, and social) with each limitation being measured using a five point scale through three questions. Looking at the motivational factors, information and entertainment motivations scored higher on the five-point scale than pass time and fan ship indicating that consumers are utilizing the use of Twitter more for information and entertainment than the other reasons that were studied. Findings from the limitations of social media users suggested that skill and social limitations had the largest effects, suggesting that consumers are looking for ways to reduce the amount of skill required to follow an athlete on Twitter in addition to emphasizing the importance of having a site that is easy to navigate and connect with players on social media. Using this information, sport organizations will be able to more effectively communicate with consumers the information that they are looking to gain from the organization while making it easier to navigate to their social media sites thus enhancing the overall user experience and receiving a more positive reaction from consumers.

With social media being such a large form of communication in today's society, sport organizations themselves are now using social media to interact with their fan bases and to reach out to potential consumers of their product. In examining whether or not differences exist in brand personality of a sporting event between those who use the specific social media page set up for the event and those who do not, Walsh, Clavio, Lovell, and Blaszka (2013) examined fans of a major National Collegiate Athletic Association Event (NCAA) to see what reasons existed to use social media. Using social media as a communication medium has many potential benefits, but this study looked to 
understand if the brand personality of a sport organization differed between consumers who use Facebook and connected with the event's Facebook page compared to those who do not use Facebook in any way.

After meeting with five managers who are responsible for brand development of the specific event at the NCAA, nine brand personality items were utilized (exciting, passionate, entertaining, intense, competitive, fan-friendly, skilled, elite, and fast-paced) and then approved by the Associated Director at the NCAA that was in charge of the event. Out of a possible 3,334 individuals, 1,523 (45.7\%) responded to the survey that was used with 440 of the respondents indicating that they had "liked" or followed the event on Facebook. Results from the study found that eight of nine brand personality items that were examined were rated significantly higher by consumers who used the NCAA event's Facebook page with "fast-paced" as the only brand personality item that was not significantly different. These results suggest that the use of social media and in this specific case Facebook may contribute to influencing an event's brand personality with consumers. It is also possible these results this could simply be due to the consumers having more exposure to the branding that took place for the event.

Watanbe, Yan, and Soebbing (2015) researched what factors have a significant effect on fans who "follow" a specific Major League Baseball (MLB) team on Twitter. This study focused on what causes daily changes to the number of Twitter followers for a sport organization as well as what can be done to keep fans as followers. Furthermore, Watanbe, Yan, and Soebbing (2015) searched to further understand how current social media strategies directly affect fan interest and fan engagement for MLB teams in 
general. The research conducted involved all 30 MLB teams over a 13-month period, allowing for an entire regular season and offseason to be analyzed.

Results from Watanbe, Yan, and Soebbing (2015) found that on average Major League Baseball teams gain 272 Twitter followers each day despite a relatively low amount of activity coming from the account. Although an MLB team "Tweeted" only 21 times per 24-hour period on average, each "Tweet" would result in five new followers over a 24-hour period. Other results from the study showed that there is no impact on how long a team has been on Twitter or the number of "Tweets" that they favorite, putting an even larger emphasis on producing content through "Tweeting" instead of other actions on Twitter. As expected in most sports, participating in the playoffs results in a large number of increased followers as an average of 433 new followers would be gained for each game played in the playoffs and nearly 2,000 Twitter followers for each day a team plays in the World Series. Even though the results of the study are significant, limitations such as focusing on only one professional sport league as well as not determining why fans are following an organization on Twitter leads to more research needing to be conducted.

\section{Ticket Sales in College Athletics}

Ticket sales vary greatly between college athletics and professional sport, as seen in a study conducted by Bouchet, Ballouli and Bennett (2011). The purpose of the study was to explore what challenges a collegiate athletic department would face when developing a ticket sales force within the athletic department rather than outsource to a third-party provider as some athletic departments have turned to. More specifically, the study looked to identify potential circumstances that causes a college athletic department 
and their ticket sales staff to struggle to keep a committed ticket sales force employed. Ticket sales at a university is a key revenue stream that accounts for nearly 30 percent of total revenue generated by an athletic department, and is usually used to fund nonrevenue generating sports in the athletic department. Other revenue streams that exist in the university system, such as donations and student fees, have caused many athletic departments to overlook the ticket sales operations force, resulting in less funding and commitment to the ticket sales operations. By looking at one, private university over a 10-year period, this study was able to see the major challenges that existed in an athletic department's ticket sales force as well as challenges that arose directly from the challenges already found.

Bouchet, Ballouli and Bennett (2011) found that a multitude of costly practices and issues arose over the 10-year period during which the study took place, leading to many different challenges. The biggest challenge was that there was a large volume of turnover at the senior leadership levels of the athletic department, which resulted in the priorities and tactics constantly changing and led to the ticket sales staff having to constantly adapt to the new priorities and tactics. Some of this can be attributed to the senior level administrators having very little if any experience with ticket sales prior to their current position in addition to the ticket sales force employees having very minimal experience with ticket sales prior to being hired. Other challenges that the ticket sales force had to face included not having proper communication throughout the entire athletic department and poor compensation plans, which ultimately led to a noncommitted sales staff and higher turnover rate at the account executive level. The disorganized communication throughout the athletic department was a direct result of 
different areas of the ticket sales force reporting to different members of the athletic department leading to pertinent information being misdirected and therefore delaying the productivity of the sales force while poor compensation to the sales force was caused by state-supported universities having bylaws that forbid administration from granting commissions or bonuses to employees. While some of the challenges that arose in the athletic department could be corrected with the adjustments, such as hiring ticket sales staff with prior experience, some of the challenges such as paying the ticket sales force incentive based sales commissions plans will always be present meaning that athletic departments will have to find new innovative ways to overcome these challenges to be successful.

\section{Spectator Motivations and Constraints for Attendance}

Different motives exist among people on why they decide to attend a collegiate sporting event, which is why Woo, Trail, Kwon and Henderson (2009) conducted research to examine and understand spectator motives and points of attachment in college football. This study was conducted to give marketers a better understanding for developing effective marketing strategies that align with the motives of fans. More specifically, this study examined four different models that explain relationships among the different motives and points of attachments to determine a model that explains the highest amount of variance in the referent variables and allowed researchers to gain a better understanding of why spectators attend college football games. Sport marketers will then be able to directly apply this knowledge and develop more effective marketing strategies that will enhance the overall consumer experience, leading to increased game attendance at future contests. 
Seven motives (vicarious achievement, acquisition of knowledge, aesthetic qualities of the game/sport, social interaction, drama, escape, and appreciation of physical skills) were used in the study and were categorized into different groups based on whether an individual is a fan or a spectator. Vicarious achievement was the only motive categorized for fans of successful teams while physical skill, aesthetic drama, and knowledge were categorized as motives for fans of unsuccessful teams for spectators. The last motives (social, escape) were considered to be overarching motives due the possibility that the motives could be applied to both groups. The results from the study showed motives for those who were fans were different from those who were only spectators, with each set of motives leading to a different set of points of attachment for both the college football fans and spectators. Of the four models, the fourth model showed the most variance with vicarious achievement and social interaction as the most likely motives for fans of specific team while skills, aesthetics, dram, and knowledge were all found to be motives of spectators. Lastly, escape was the only motive found to be connected to both groups and not social interaction although this is believed to be because social interaction is more likely to occur when winning is valued by fans and spectators.

Trail, Robinson, and Kim (2008) focused on creating a list of possible constraints that existed to attending a sporting event and how each of these constraints differed between males and females as well as attendees from non-attendees. Prior research in sport and leisure found that certain things such as financial cost and alternative sport entertainment had an effect on spectator's decision to not go to an event, but no defined list has been created to define these constraints. Furthermore, prior research had not 
looked at the possibility of gender differences existing in these constraints, leading to the need for this study. Using a paper and pencil survey in conjunction with an NCAA Divison I athletic department, Trail Robinson, and Kim (2008) were able to collect data on 59 potential structural constraints to attending a sporting event.

Results from Trail, Robinson, and Kim's (2008) study showed that 15 distinct structural constraint dimensions (six venue-based, nine non-venue based) constraints existed. The venue based aspects included concessions, restrooms, seating, cleanliness of venue, professionalism of staff, and parking while the non-venue aspects included alternative leisure activities, alternative sports entertainment, financial cost, lack of team success, social commitments, stadium location, game on radio/TV, and work/school commitments. Nine other constraint items were tested but did not represent additional dimensions or were poor items (Trail, Robinson, Kim, 2008). Additionally, it was found that no significant differences existed between males and females or attendees and nonattendees on venue related constraints. Three non-venue constraints did prove significant between males and females, but could be due to different leisure activity examined, a different sample, different items, or a combination of the three.

Not much research has been conducted at lower levels of college athletics, leading Jensen and DeSchriver (2002) to focus on analyzing the relationship between spectator attendance at NCAA Division II football games. The study was conducted by using selected determinants by estimating economic demand models over a course of three seasons of play $(1994,1996,1999)$. The two key determinants analyzed throughout the study were winning percentage of the teams and promotional activity that took place for said game. Other determinant factors included the number of enrolled students at the 
college and the marketing competition that the football contest had to compete with. With nine percent of all Division II athletic revenues being generated by ticket sales to home contests, attendance is a key component for all NCAA Division II athletic programs that are unable to rely upon other sources of revenue such as media rights fees and luxury seating. By creating an economic demand model to empirically identify the different determinants that are directly related to spectator attendance at NCAA Division II football games, athletic administrators will be able to better identify successful marketing strategies to increase both attendance and revenue at NCAA Division II football games.

Out of 147 NCAA Division II football teams that played in each of the three years that data were collected, an average of 86 teams responded each year of the study, which accounted for a total of $59 \%$ of all NCAA Division II football teams at the time. Results of the study found that while current team winning percentage would not have any significance during the beginning of the season and increase in significance as the season went on, previous season winning percentage was found to be significant during the early portion of the season ( 3 games) before declining throughout the rest of the season. Promotional events such as homecoming increased attendance by approximately double what any other promotion would increase attendance by, although less than half (40.4) of non-homecoming games had any sort of promotion tied to them. Factors that had very little significance in determining attendance were the age of the stadium and the distance between the two competing teams while two factors that are uncontrollable by the athletic administration (student population and weather) were significantly related to attendance. Other determinants included in the study were the time of year the contest was being played, which suggested that attendance will decrease as the season progresses. 
Additionally, the increase in the number of televised games on a national level has increased which suggests a decrease in attendance as consumers are staying home and watching televised games.

James and Ross (2004) expanded upon the understanding of sport consumers by identifying which motives influenced an individual's interest in "non-revenue generating" collegiate sports while determining whether similar motives influenced their consumption across multiple "non-revenue generating" sports. This study came about due to the challenges that many intercollegiate athletics programs are facing in regards to generating more revenue to offset the costs associated with "non-revenue generating" sports. For intercollegiate athletic departments to successfully generate these revenues to help offset the costs, the department must first understand the motives that drive consumer interest in these "non-revenue generating" sports to be able to develop promotional campaigns to foster increased attendance to help offset the costs. Furthermore, athletic departments must understand the difference between sport-related motives, motives pertaining to self-definition, and motives related to personal benefits, to be able to develop a successful promotional campaign that will lead to increase revenues. Results from three “non-revenue generating” sports (men's baseball, women's softball, men's wrestling) indicated that consumer interest in sporting events was based on motives and factors that were associated with sports in general. Sport-related motives (entertainment, skill, drama, and team effort) were rated higher by consumers than both the motives pertaining to self-definition (achievement, empathy, team affiliation) and motives tied to personal benefits (social interaction, family). These findings not only support the authors' claim that consumers of sport attend college sporting events based 
on the enjoyment of watching athletes give their maximum efforts in a sport that they strive to play, but also because the findings suggest that the consumers are interested in components of sporting events that are easily promoted. When looking at each of the three sports on an individual basis, consumers of wrestling rated all of the motives higher than the baseball and softball consumers while softball consumers rated all but one motive (social interaction) higher than baseball consumers. Based off the findings of each sport individually, the study suggests that baseball consumers are attending purely for the entertainment value, although other motives not measured as well as demographic characteristic differences between the sports could also be a reason for baseball consumers to rate highly in entertainment value. As a whole, the results reveal that for intercollegiate athletic departments to successfully generate more revenue in "nonrevenue" generating sports, marketers must have an expanded appreciation of sport consumer motivations that cut across different sports as well as those that are unique to specific sports.

\section{Students as Fans}

College students tend to have different motives and points of attachment for attending collegiate athletic events, which led Swanson, Gwinner, Larson and Janda (2003) to examine four individual psychological motivations (team identification, eustress, group affiliation, and self-esteem enhancement) to see how they relate to attending a sporting event. While examining these psychological motivations, the study also sought to find out whether or not gender differences had any impact on these motivations. Additionally, research considering fan-initiated word-of-mouth was looked at as a second outcome variable to develop a better understanding of how these 
differences can affect attendance of a sporting event. Prior to this study, very little previous research existed regarding gender differences in terms of sport spectators, and what research had been completed had inconsistent findings. Due to the fact that ticket sales represents such a substantial amount of income for many sport organizations, results from this study could make an immediate impact regarding marketers and the ways that sport events are marketed to the different genders.

Results from the study found that of the four psychological factors, team identification and a fan's perceived connectedness to the team were successfully used to predict attendance and word-of-mouth communication impact. Group affiliation was found to also have a significant impact on both of these outcome variables, indicating to sport marketers that group-friendly environments are more likely to lead to increased game attendance. When looking at gender differences, arousing emotional stimulation directly leads to planned attendance for men only, suggesting that eustress was associated with team sports that are aggressive in nature. On the other hand, focusing on the communal atmosphere and the interpersonal aspects of the spectator experience was more likely to generate positive word-of-mouth communication among females. Based off this information, marketers must decide whether to market the excitement and emotional stimulation aspect of a sporting event to improve male attendance, or focus on the communal atmosphere to gear the event towards women.

Ferreira and Armstrong (2004) compared and contrasted men's and women's college hockey and basketball games in hopes to determine what attributes are more likely to draw students to specific sporting events. This study focused solely on the factors that influence different aspects of the purchase cycle regarding each individual's 
evaluation of the sport product. In total there were 41 different attributes that were viewed to further understand the sport consumers' preference in attending the events rather than an alternative. The study was conducted in a two-stage process with the first being used to identify important attributes students associated with college sport event attendance while stage two focused on the determining factors used by students' for attendance when presented with four sport event alternatives.

Results from stage one of the study indicated students used a wide range of identifiable factors that were influential in their decision to attend one event over the other with the factors that were identified by direct questioning not differing from the factors already identified in previous studies. Factors listed ranged anywhere from the descriptions of the sport event as a core product to the price of tickets and facility conditions from which four criteria (sports that were played during the same season, sports that were available to both genders, sports that varied in attendance levels, and sports that were considered team sports) were then used to determine the four sports. Stage two results found that determinant attributes that most differentiated the sports were the ones directly related to core sport product characteristics with the physical contact in the sport and popularity of the sport as the two biggest attributes. Overall the results found that by focusing on key attributes tied to each sport (physical contact with men's hockey, pre-game and in-game entertainment for men's basketball), marketers are likely to see better overall attendance than compared to marketing attributes that did not perform well (cost and promotions for men's basketball).

Peetz (2010) examined the development of a student rewards program to see if creating a rewards program was a viable solution for collegiate athletic departments that 
have difficulty "selling" out their allotment of free student tickets to less marquee games. This first problem also led to an issue of a non-energized atmosphere and decrease in potential revenue for that particular game. Furthermore, collegiate athletic departments have little problem selling out of their allotment in quick fashion for marquee games against conference opponents and rivalry games, which can cause casual fans to no longer support the team because of the constant influx of support by others. This issue is becoming even more profound as collegiate athletic departments are faced with situations where they have seen a rise in expenses while also a decrease in funding. The most common solution to these problems presented has been to use a rewards system for the students that would tie in entry into the "marquee games" and other perks based on the individual student's attendance at games leading up to the "marquee" game.

By using a rewards system as a way to increase student attendance at less marquee games to gain priority admission into "marquee" games, one collegiate athletic program (Kansas State University) was able to increase their student attendance at games by 18.2 percent from the previous year. In addition to seeing the average attendance at men's basketball games go up 1,246 students per game, KSU was able to successfully expand their student ticketing rewards program to other sports on campus and see an overall rise in student attendance at all sporting events. While the creation of a rewards program was found to be successful in this study, the author is also quick to point out that other factors that influence motivation to attend the events must also be addressed before creating a successful rewards program. Thing such as marketing strategies to notify students of the rewards program, using the marketing strategy to meet the needs and wants of the students as well as emphasizing on the social aspect that takes place when 
attending the event can all help make a rewards program fitted towards a specific student body. 


\section{CHAPTER III METHODOLOGY}

This chapter describes the research design and methods used to conduct this study, the study participants and methods of recruitment, and the method of instrumentation. Finally, this chapter addresses the timeline of the data collection process. The purpose of this study is to compare Twitter usage patterns between student ticket membership buyers and non-buyers. In working toward this purpose, this study seeks to shed light on the role social media and constraints for attending a game may be playing in student decisions to purchase ticket memberships to sporting events. This will allow us to gain a deeper understanding of student populations in sport and the relevance of social media marketing for college athletic departments. The group researched in the study (called Red Alert) is a student spirit membership group that costs $\$ 50$ per year and allows members admission to all regular-season home athletic events for football and men's basketball (without membership, cost is $\$ 5$ per game). In addition to gaining admission to all remaining regular-season home athletic events for all other sports, Red Alert members also are admitted 15 minutes earlier than the general public to football, men's and women's basketball and volleyball in addition to being given one official Red Alert Tshirt. To address this study's purpose the following research questions have been developed: 


\section{Research Questions}

RQ1: Are Red Alert members more involved (interaction including "likes", "retweets" and "favorites") with the @ISURedbirds Twitter account than non-Red Alert members? RQ2: Do Red Alert members use Twitter with greater intensity (spend more time on Twitter than others and feel a connectedness that they cannot find elsewhere) than nonRed Alert members?

RQ3: Do Red Alert members feel less constrained to attend games than non-members?

\section{Research Design}

This study will use a quantitative survey design. Using a quantitative research survey design will allow for convenience sampling, making the study more feasible to collect data. One purpose of this study is to determine if higher intensity and time spent using Twitter among college student's results in higher behavioral intent and purchase intentions to purchase tickets to sporting events.

\section{Data Collection Procedures}

Using convenience sampling, five undergraduate level classes at Illinois State University in the Kinesiology and Recreation department were asked to participate in a paper and pencil survey prior to class. Each class contained 20-30 undergraduate students for a total of 117 students. The survey instrument was distributed to every student in class on the day that the study was conducted with each student reserving the right not to participate. No incentives were offered for participation or to those who choose to participate. 


\section{Survey Instrument}

A survey instrument was adapted from two previously tested questionnaires from the areas of communication and marketing. The first survey instrument was utilized to measure the relationship between the use of Facebook (Facebook intensity) and maintaining social capital (Ellison, Steinfield and Lampe, 2007). The second survey instrument (Zaichowski, 1994) focused on measuring consumer brand involvement and consumer brand interest to determine if more consumer involvement with a brand was related to the amount of engagement a consumer had with a brand. In order to adapt the first survey instrument, it was necessary to change the social media site from Facebook to Twitter as the present study focuses on Twitter intensity. As previously used in the original survey instrument, the differing scale range was kept as a construct to measure twitter use in relation to intensity. The second survey instrument also needed a minor change to meet the needs of the study, as the social media site was changed from LinkedIn to Twitter. Additionally, typical demographic data such as age, year in school, in state vs. out of state residency and ethnicity will also be included to the final survey instrument for descriptive purposes and determination of whether or not the student is a Red Alert member.

\section{Study Variables}

This study includes both dependent and independent variables. The independent variable in this study (Red Alert membership) is related whether or not a student currently is a Red Alert member. The dependent variables (Twitter intensity, consumer involvement, and constraints for attending a game) are specifically related to the construct being measured in the survey. The Twitter intensity variable comes from six 
general questions regarding Twitter and a student's use towards Twitter using a six-point Likert scale. The questions are as follows: Twitter is part of my every day activity, I'm proud to tell people I am on Twitter, Twitter has become part of my daily routine, I feel out of touch when I haven't checked Twitter for awhile, I feel I am part of the Twitter community, and I would be sorry if Twitter were shut down.

Dependent variable two (consumer involvement) is gauged by using 10 questions on a seven-point Likert scale with a word on each side of the scale with the student selecting the number nearest to the word they feel best describes the official Twitter account of ISU Redbird Athletics (@ISURedbirds).

The third and final dependent variable used a six-point Likert scale asking six questions that could constrain a student from attending a game. The constraints are as follows: I have too many work/school commitments to go to Redbird games, It is too expensive to be a Red Alert member, I'd rather go watch at a bar/restaurant than go to a stadium/arena, It's too inconvenient to travel to a game, It's not worth trying to find parking at a game, and I would rather just watch Redbird games at home on TV.

\section{Data Analysis}

A series of independent samples t-tests were conducted to examine the differences between Red Alert members and non-members for each of the variables in the survey instrument. By using an independent samples t-test, this study was able to compare whether two groups have different average values for each of the separate variables. The independent samples t-test is able to answer if there are significant differences based on overall Twitter intensity between Red Alert and Non-Red Alert members as well as if any significance differences exist based on consumer involvement with@Redbird Athletics 
between Red Alert and non-Red Alert members. Basic descriptive statistics were also used to gather information regarding student demographic information. 


\section{CHAPTER IV}

\section{RESULTS}

The previous chapter reviewed the method used to test the research questions that were presented for this thesis. The chapter describes the participants, the data collection, and data analysis used to test the hypotheses used in chapter III. The findings of this study will help to understand the differences between students that Twitter has on their intentions to purchase a ticket membership to attend athletic events. In particular, the statistical findings show what differences exist between students who are Red Alert members and non-members with their social media use and feelings towards particular constraints that hinders a student from attending a game.

The survey used was handed out in five classes to a total of 117 individuals with 102 respondents for an effective response rate of $87.2 \%$. The respondents consisted of $62.7 \%$ females $(n=64)$ and $37.3 \%$ males $(n=38)$ compared to a typical institutional enrollment of $54.7 \%$ female and $45.3 \%$ male. Additionally, $48 \%$ of respondents were in either their first or second year at the university $(n=49), 39.2 \%$ in their third year $(n=40)$, and $12.8 \%$ of the respondents were in their fourth or more year at the university $(n=13)$. When compared to the entire undergraduate population, these percentages are comparable (45.4\% first or second year students, 24.6 third year and 30\% in their fourth or more year) but are leaning towards being outside the range of comparability. Of the total respondents, 15 participants $(14.7 \%)$ indicated that they were "Red Alert members" and 84 participants $(82.4 \%)$ indicated that they were not "Red Alert" members. When 
compared to the total number of Red Alert members at Illinois State University $(3,700$ students or $20.5 \%)$ to the total undergraduate campus population $(18,012$ students or (79.5\%), the numbers are similar to those found in the research study. Further examination of the data showed that $44.1 \%$ of respondents fell in the age range of $18-20$ $(n=45), 52 \%$ were in the age range $21-23(n=53)$, and only $3.9 \%$ were 24 or older $(n=4)$. These results are also found to be comparable to the overall undergraduate student population numbers on campus (45.4\% ages $18-20,52.6 \%$ ages $21-23$, and $2.0 \%$ ages 24 or older).

The results indicate that Red Alert members are significantly more likely to follow@ISURedbirds than non-members $(\mathrm{p}<.01)$, but there was no relationship of significance found indicating that Red Alert members are more involved with the @ISURedbirds Twitter account than non-members $(\mathrm{p}=.12)$. A Pearson Chi-Squared statistic was calculated to confirm these findings $(\mathrm{p}<.001)$. These results indicate that no differences exist in involvement between Red Alert members and non-members.

Table 1

Cross Tabulation Analysis

\begin{tabular}{lll}
\hline Variable & Red Alert member (15) non-member (84) & $\begin{array}{l}\text { Pearson Chi-Square } \\
\text { p value }\end{array}$
\end{tabular}

\begin{tabular}{llcl}
\hline Follow@ISURedbirds & 13 & 26 & .000
\end{tabular}

Results also indicate there are no significant differences between members and non-members based on Twitter intensity or the amount of time using Twitter. Out of the 10 dependent variables that were measured, only two variables measured to be significantly different (Following@ISURedbirds on Twitter $\{\mathrm{p}=.00\}$ and the constraint statement "I'd rather go watch at a bar/restaurant than go to a stadium/arena" $\{p=.00\})$. 
The other eight variables that were measured were not statistically significant between the two groups. Looking specifically at research question three (Do Red Alert members feel less constrained to attend games than non-members?), the findings show that Red Alert members do not feel less constrained to attend games compared to non-members in five of the six constraint areas.

Table 2

T-test Analysis on Twitter Intensity and Consumer Involvement

\begin{tabular}{lcll}
\hline Variable & Red Alert member (15) & non-member (84) & p value \\
Follow@ISURedbirds & 1.133 & 1.690 & .000 \\
Involvement & 28.333 & 35.478 & .262 \\
Twitter Intensity & 3.244 & 3.023 & .658 \\
MinutesDay & 4.600 & 4.195 & .123 \\
& & & \\
\hline
\end{tabular}

Reliability statistics according George and Mallery (2003) for the Twitter intensity scale indicated a good reliability with a Cronbach's alpha coefficient of .952 . Additionally, Zaichkowsky's (1994) engagement scale also indicated good reliability according to George and Mallery (2003), with a Cronbach's alpha coefficient of .959. To measure perceived constraints of attendance, a series of single-item measures were used. According to Kwon and Trail (2005), these types of single-item measures are appropriate in an applied sport marketing research context.

Table 3

T-tests Analysis on Constraints

\begin{tabular}{lllc}
\hline \multicolumn{1}{l}{ Variable } & Red Alert member (15) & non-member (84) & p value \\
\hline $\begin{array}{l}\text { I have too many work/school } \\
\text { commitments to go to Redbird games. }\end{array}$ & 3.400 & 3.654 & .213 \\
$\begin{array}{l}\text { It is too expensive to be } \\
\text { a Red Alert member. }\end{array}$ & 2.600 & 3.011 & .214 \\
& & & (Table Continues)
\end{tabular}




\begin{tabular}{lclc}
\hline Variable & Red Alert member (15) & non-member (84) & p value \\
\hline $\begin{array}{l}\text { I'd rather go watch at a bar/restaurant } \\
\text { than go to the stadium/arena. }\end{array}$ & 2.800 & 3.523 & .008 \\
$\begin{array}{l}\text { It's too inconvenient to } \\
\text { travel to a game. }\end{array}$ & 2.600 & 2.988 & .268 \\
$\begin{array}{l}\text { It's not worth trying to find } \\
\text { parking at a game. }\end{array}$ & 3.400 & 3.571 & .274 \\
$\begin{array}{l}\text { I would rather just watch Redbird } \\
\text { games at home on TV. }\end{array}$ & 2.600 & 3.202 & .385 \\
\end{tabular}




\section{CHAPTER V \\ DISCUSSION}

\section{Summary of the Research Findings}

The previous chapter described the findings of the research questions in chapter three. The results indicated that students who had purchased a Red Alert membership are more likely to follow @ISURedbirds, the official Twitter handle of the university athletics program compared to non-Red Alert members., In addition, Red Alert members are also more likely to disagree with the statement that they would rather watch a sporting event at a bar or restaurant instead of attend the event in person compared to non-Red Alert members. Five other constraints to attending a game were measured as well as four other variables were tested, but no significant differences between Red Alert members and non-members were found.

Non-significant findings from the first research question suggest that student interaction with@ISURedbirds Twitter does not change regardless of whether or not a student is a Red Alert member. This finding suggests that students are not connecting with brands on social media, thus suggesting that the marketing message is not reaching the intended consumer base. While the research did find that those who are Red Alert members are significantly more likely to follow@ISURedbirds on Twitter, this would indicate that Schultz and Peltier's (2013) findings that a majority of marketing initiatives are being directed towards consumers that are already engaged with their brand. 
The results of the second research question suggest that students do not use Twitter with a greater intensity or spend more time using Twitter dependent of whether or not they follow@ISURedbirds on Twitter, indicating that Twitter may not play as big of role in the student purchase process. The Third research question only yielded one significant finding in regards to the constraint "I' $\mathrm{d}$ rather go watch at a bar/restaurant than go to the stadium/arena" suggesting that student constraints for attending a game are the same for both Red Alert members and non-members. This result would suggest that regardless of whether or not a student is a ticket membership holder, they feel the same constraints for attending as those who do not hold a ticket membership package.

Ideally, this research project would have been able to fill the gap that has been made in previous research such as the relationship between following a brand (@ISURedbirds on Twitter) and purchasing a membership for that brand (Red Alert membership) or how a brand using Twitter is meeting the needs of millennial consumers. Social media shows no signs of slowing down from its current state, and has new users joining daily making the audience to which messages are marketed to even larger. While the current research indicated that those who purchased a membership are more likely to follow@ISURedbirds on Twitter and choose to attend a game over watching elsewhere compared to non-Red Alert members, the research does not look into how many students are actually attending games that have purchased memberships.

For Redbird Athletics, the findings present in this research study provide a series of possible recommendations to take into consideration. First, Redbird Athletics should find other mediums besides Social Media to try and grow their Red Alert membership brand as the results show Red Alert members are more likely to follow @ISURedbirds on 
Twitter compared to non-members. Secondly, of the constraints measured in the current study, the only constraint to test significantly different between Red Alert members and non-members is that Red Alert members are more likely to want to watch a game in a stadium/arena instead of at a bar/restaurant. This means that one potential solution to getting non-Red Alert members to become members is to offer alcoholic beverages at games where students who are of age can partake. Another possible solution would be to create a shuttle system for before and after an event that would pick students up at bar and restaurant establishments within a certain area from the event and drop them off following.

\section{Study Limitations}

As is the case with any research, there are limitations to the present study. Because the research conducted uses only undergraduate students from Illinois State University, the results found may only represent undergraduate students at Illinois State University and not at colleges in other parts of the country. All five of the classes that received the survey are classes that take place in the department of Kinesiology and Recreation, leading to another potential limitation as students in one specific academic department of a college may not be representative of students in other academic departments. The survey instrument for the present study was adapted from two original surveys including one utilized to gather information across another discipline. While the instrument was adapted to meet the needs of the current study, this could still be seen as a limitation. 


\section{Future Research Considerations}

Future research conducted should focus on the number of students using their membership to attend games relative to how many students have purchased a membership as a way to better suit membership packages for students to get the most value of the membership. By better suiting membership packages for students to get the most possible value out of, the students are more likely to become repeat purchasers and talk other students into purchasing thus maximizing potential value for both the brand and consumer. Furthermore, additional research regarding constraints for student attendance at game should be studied in more detail to further understand what possible reasons exists for students not to attend games. It should also be noted that future research is needed to more fully explore the concept of social media involvement as results from the current studies show that Red Alert members are more likely to follow @ISURedbirds compared to non-members.

In summary, this research study examined the role that Twitter and marketing plays in purchase intentions of students that actually purchase ticket memberships compared to non-ticket membership purchasers and what constraints exist for not attending. While the study found that Red Alert members are more likely to follow @ISURedbirds on Twitter compared to non-members, no significant results were found on whether Red Alert members use Twitter with a greater intensity than non-members. Furthermore, non-significant findings were found for five of six constraints that were tested for attending a game, meaning that both Red Alert members and non-members feel constrained to attend games. This study attempted to help further understand how to better market products to students and the millennial generation in hopes to better market 
products to them. More research is needed to fully understand how many students are actively using their Red Alert membership package as well as social media involvement to produce more effective marketing messages through the use of social media. 


\section{REFERENCES}

Ashley, C., \& Tuten, T. (2015). Creative Strategies in Social Media Marketing: An Exploratory Study of Branded Social Content and Consumer Engagement. Psychology \& Marketing, 32(1), 15-27. doi:10.1002/mar.20761

Berkowitz, S. (2015, January 14). How cost of attendance may become a recruiting tool. Retrieved November 5, 2015.

Bouchet, A., Ballouli, K., \& Bennett, G. (2011). Implementing a Ticket Sales Force in College Athletics: A Decade of Challenges. Sport Marketing Quarterly, 20(2), $84-92$.

Bourdieu, P., \& Wacquant, L. (1002). An Invitation to Reflexive Sociology. Chicago: University of Chicago Press.

Brodzky, B. (2014, November 18). Social Media User Statistics \& Age Demographics for 2014. Retrieved January 4, 2016, from https://www.linkedin.com/pulse/20141118182103-28964915-social-media-userstatistics-age-demographics-for-2014

Carlson, A., \& Lee, C. C. (2015). FOLLOWERSHIP AND SOCIAL MEDIA MARKETING. Academy Of Marketing Studies Journal, 19(1), 80-101.

Carmin, M. (2014, April 26). Big Ten schools expect big payouts to continue. Retrieved September 28, 2015. 
Culnan, M. J., McHugh, P. J., \& Zubillaga, J. I. (2010). HOW LARGE U.S. COMPANIES CAN USE TWITTER AND OTHER SOCIAL MEDIA TO GAIN BUSINESS VALUE. MIS Quarterly Executive, 9(4), 243-259.

Ferreira, M., \& Armstrong, K. L. (2004). An Exploratory Examination of Attributes Influencing Students' Decisions to Attend College Sport Events. Sport Marketing Quarterly, 13(4), 194-208.

Fiegerman, S. (2013, August 15). This Is What Facebook's First Ads Looked Like. Retrieved January 4, 2016, from http://mashable.com/2013/08/15/facebook-firstad/\#D1N8zqxOMZqP

George, D., \& Mallery, P. (2003). SPSS for Windows step by step: A simple guide and reference. 11.0 update (4th ed.). Boston: Allyn \& Bacon.

Goodrich, K., \& Mooij, M. (2013). How 'social' are social media? A cross-cultural comparison of online and offline purchase decision influences. Journal of Marketing Communications, 103-116.

Hosick, M. (2015, January 18). Autonomy schools adopt cost of attendance scholarships. Retrieved November 6, 2015.

Jackson, E. L. ( !997). In the eye of the beholder; A comment on Samdahl \& lekubovich ( 1997\}, "A Critique of leisure constraints: Comparative analyses and understandings." journal of Leisure Research, 29, 458-46

James, J. D., \& Ross, S. D. (2004). Comparing Sport Consumer Motivations Across Multiple Sports. Sport Marketing Quarterly, 13(1), 17-25.

Jensen, P. E., \& DeSchriver, T. D. (2002). Determinants of Spectator Attendance at NCAA Division II Football Contests. Journal Of Sport Management, 16(4), 311. 
King, B. (2005, December 5). Race For Recruits. Retrieved November 5, 2015.

Kornblum, J. (2006, September 11). Facebook will soon be available to everyone USATODAY.com. Retrieved November 3, 2015.

Kwon, H., \& Trail, G. (2005). The feasibility of single-item measures in sport loyalty research. Sport Management Review, 8(1), 69-88.

MAC and ESPN Announce Historic 13-Year Right Extension Deal Through 2026-27 Season. (2014, August 19). Retrieved December 2, 2015, from http://macsports.com/news/2014/8/19/GEN_0819145904.aspx

Muijs, D. (2004). Doing quantitative research in education with SPSS. London: SAGE. Nair, M. (2011). Understanding and measuring the value of social media. Journal Of Corporate Accounting \& Finance (Wiley), 22(3), 45-51. doi:10.1002/jcaf.20674

Orszag, J., \& Israel, M. (2009, February 1). THE EMPIRICAL EFFECTS OF COLLEGIATE ATHLETICS : AN UPDATE BASED ON 2004-2007 DATA. Retrieved November 3, 2015.

Peetz, T. B. (2011). Marketing the 'Big Game': Developing a Student Rewards Program in College Basketball. Sport Marketing Quarterly, 20(2), 115-121.

Prisbell, E. (2014, August 17). What is full cost of attendance for NCAA athletes? Retrieved November 5, 2015.

Rosendale, J. A. (2015). New Communication Technologies in Organization Communications and Branding: The Integral Role Social Media Now Play. Florida Communication Journal, 43(2), 49-59.

Sashi, C. (2012). Customer engagement, buyer-seller relationships, and social media. Management Decision, 50(2), 253. doi:10.1108/00251741211203551 
Schultz, D. E., \& Peltier, J. (. (2013). Social media's slippery slope: challenges, opportunities and future research directions. Journal Of Research In Interactive Marketing, 7(2), 86. doi:10.1108/JRIM-12-2012-0054

Schwabel, D. (2013, September 4). Why You Can't Ignore Millennials. Retrieved January 4, 2016, from http://www.forbes.com/sites/danschawbel/2013/09/04/why-youcant-ignore-millennials/

Sheehan, K., \& Morrison, D. (2009). The creativity challenge: Media confluence and its effects on the evolving advertising industry. Journal of Interactive Advertising, 9, $40-43$.

Steinbach, P. (2013, June 1). Schools Strategize to Increase Student Football Attendance - Athletic Business. Retrieved November 7, 2015.

Swanson, S. R., Gwinner, K., Larson, B. V., \& Janda, S. (2003). Motivations of College Student Game Attendance and Word-of-Mouth Behavior: The Impact of Gender Differences. Sport Marketing Quarterly, 12(3), 151-162.

Trail, G. T., Robinson, M. J., \& Yu Kyoum, K. (2008). Sport Consumer Behavior: A Test for Group Differences on Structural Constraints. Sport Marketing Quarterly, 17(4), 190-200.

Walsh, P., Clavio, G., Lovell, M. D., \& Blaszka, M. (2013). Differences in Event Brand Personality Between Social Media Users and Non- Users. Sport Marketing Quarterly, 22(4), 214-223.

Watanabe, N., Yan, G., \& Soebbing, B. P. (2015). Major League Baseball and Twitter Usage: The Economics of Social Media Use. Journal Of Sport Management, 29(6), 619-632. doi:10.1123/JSM.2014-0229 
Weiner, J. (2010, June 1). Knight Commission on Intercollegiate Athletics -Chapter 2: Expenses. Retrieved November 5, 2015.

Witkemper, C., Choong Hoon, L., \& Waldburger, A. (2012). Social Media and Sports Marketing: Examining the Motivations and Constraints of Twitter Users. Sport Marketing Quarterly, 21(3), 170-183.

Woo, B., Trail, G. T., Kwon, H. H., \& Anderson, D. (2009). Testing Models of Motives and Points of Attachment among Spectators in College Football. Sport Marketing Quarterly, 18(1), 38-53.

Zaichkowsky, J. L. (1986). Conceptualizing Involvement. Journal of Advertising, 15(2), $4-34$.

Zaichkowsky, J. L. (1994). The Personal Involvement Inventory: Reduction, Revision, and Application to Advertising. Journal of Advertising, 23(4), 59-70. Retrieved March 1, 2016. 


\section{APPENDIX A}

\section{SURVEY INSTRUMENT}

Please answer the questions that follow by circling the appropriate response or filling in the blank provided.

Are you a "Red Alert" member? Yes No Nore

Do you follow the official Twitter account of ISU Redbird Athletics (@RedbirdAthletics)?_Yes_No

Approximately how many people do you follow on Twitter?

Unsure

Approximately how many people follow you on Twitter?

In the past week (an average) how many minutes per day did you spend on Twitter?

Please rate your overall level of agreement with each of the following statements:

\begin{tabular}{|c|c|c|c|c|c|c|}
\hline & $\begin{array}{l}\text { Strongly } \\
\text { Disagree }\end{array}$ & Disagree & $\begin{array}{c}\text { Somewhat } \\
\text { Disagree }\end{array}$ & $\begin{array}{l}\text { Somewhat } \\
\text { Agree }\end{array}$ & Agree & $\begin{array}{l}\text { Strongly } \\
\text { Agree }\end{array}$ \\
\hline Twitter is part of my every day activity. & $\circ$ & ○ & $\circ$ & O & o & o \\
\hline I'm proud to tell people I am on Twitter. & O & o & o & ○ & o & ○ \\
\hline $\begin{array}{l}\text { Twitter has become part of my daily } \\
\text { routine. }\end{array}$ & o & o & o & o & o & o \\
\hline $\begin{array}{l}\text { I feel out of touch when I haven't checked } \\
\text { Twitter for awhile. }\end{array}$ & o & o & o & o & o & o \\
\hline I feel I am part of the Twitter community. & o & o & o & o & o & o \\
\hline $\begin{array}{l}\text { I would be sorry if Twitter were shut } \\
\text { down. }\end{array}$ & o & o & o & ○ & o & $\circ$ \\
\hline
\end{tabular}


Please circle the number nearest to the word you feel best describes the official Twitter account of ISU Redbird Athletics (@RedbirdAthletics).

$\begin{array}{lcccccccc}\text { Unimportant } & 1 & 2 & 3 & 4 & 5 & 6 & 7 & \text { Important } \\ \text { Boring } & 1 & 2 & 3 & 4 & 5 & 6 & 7 & \text { Interesting } \\ \text { Irrelevant } & 1 & 2 & 3 & 4 & 5 & 6 & 7 & \text { Relevant } \\ \text { Unexciting } & 1 & 2 & 3 & 4 & 5 & 6 & 7 & \text { Exciting } \\ \text { Means nothing } & 1 & 2 & 3 & 4 & 5 & 6 & 7 & \text { Means a lot } \\ \text { Unappealing } & 1 & 2 & 3 & 4 & 5 & 6 & 7 & \text { Appealing } \\ \text { Mundane } & 1 & 2 & 3 & 4 & 5 & 6 & 7 & \text { Fascinating } \\ \text { Worthless } & 1 & 2 & 3 & 4 & 5 & 6 & 7 & \text { Valuable } \\ \text { Uninvolving } & 1 & 2 & 3 & 4 & 5 & 6 & 7 & \text { Involving } \\ \text { Not needed } & 1 & 2 & 3 & 4 & 5 & 6 & 7 & \text { Needed }\end{array}$

\section{Please rate your overall level of agreement with each of the following statements:}

\begin{tabular}{|c|c|c|c|c|c|c|}
\hline & $\begin{array}{l}\text { Strongly } \\
\text { Disagree }\end{array}$ & Disagree & $\begin{array}{c}\text { Somewhat } \\
\text { Disagree }\end{array}$ & $\begin{array}{l}\text { Somewhat } \\
\text { Agree }\end{array}$ & Agree & $\begin{array}{c}\text { Strongly } \\
\text { Agree }\end{array}$ \\
\hline $\begin{array}{l}\text { I have too many work/school } \\
\text { commitments to go to Redbird games. }\end{array}$ & o & ○ & o & o & o & o \\
\hline $\begin{array}{l}\text { It is too expensive to be a Red Alert } \\
\text { member. }\end{array}$ & ० & o & o & ○ & o & o \\
\hline $\begin{array}{l}\text { I'd rather go watch at a bar/restaurant than } \\
\text { go to the stadium/arena. }\end{array}$ & ○ & ० & o & o & o & o \\
\hline It's too inconvenient to travel to a game. & ○ & ○ & o & o & o & ० \\
\hline $\begin{array}{l}\text { It's not worth trying to find parking at a } \\
\text { game. }\end{array}$ & ○ & o & o & o & o & o \\
\hline $\begin{array}{l}\text { I would rather just watch Redbird games } \\
\text { at home on TV. }\end{array}$ & ○ & o & o & o & o & o \\
\hline
\end{tabular}

\section{Please tell us a little about yourself.}

1) Please indicate your age.

$$
\text { ○ } 18-20 \text { o } 21-23 \text { o } 24-25
$$

2) Please indicate your gender.
- Male
○ Female
- Prefer not to respond 
3) To measure the diversity of our attendees, please identify your ethnic background.

- Hispanic o Caucasian o African American o Asian/Pacific Islander o Native American o Other

○ Prefer not to respond

4) What year at Illinois State is this for you as a student?

$\circ 1^{\text {st }}$ o $2^{\text {nd }} \circ 3^{\text {rd }} \circ 4^{\text {th }}$ o $5^{\text {th }}$ o $6^{\text {th }}$ or more

THANK YOU FOR YOUR PARTICIPATION! 